\title{
Erratum
}

\section{Lung (DOI: 10.1007/s00408-004-7514-9), published in vol 182/no 6, pp 355-362, 2004}

Several reference numbers were inadvertently duplicated in the Reference section of the article "Marital Status and Sleep-disordered Breathing in a Sample of Middle-aged French Men", by D. Teculescu, B. Hannhart, J.-M. Virion, B. Montaut-Verient, and J.-P. Michaely. Below is the correct reference list:

\section{References}

1. Armenian HK, Saadeh FM, Armenian SL (1987) Widowhood and mortality in an Armenian church parish in Lebanon. Am J Epidemiol 125:127-132

2. Ancoli-Israel S, Klauber MR, Kripke DF, et al. (1989) Sleep apnea in female patients in a nursing home. Increased risk of mortality. Chest 96:1054-1058

3. Ben-Shlomo Y, Smith GD, Shipley M, Marmot MG (1993) Magnitude and causes of mortality differences between married and unmarried men. J Epidemiol Community Health 47:200-205

4. Breslau N, Roth T, Rosenthal L, Andreski P (1997) Daytime sleepiness: an epidemioiogical study of young adults. Am J Publ Health 87:1649-1653

5. Davis MA, Neuhaus JM, Moritz DJ, Segal MR (1992) Living arrangements and survival among middle-aged and older adults in the NHANES I Epidemiologic Follow-up Study. Am J Publ Health 82:401-406

6. Deckert T, Poulsen JE (1968) Prognosis for juvenile diabetics with late diabetic manifestations. Acta Med Scand 183:351-356

7. Enright PL, Newman AB, Wahl PW, et al. (1996) Prevalence and correlates of snoring and observed apneas in 5,201 older adults. Sleep 19:531-538

8. Grunstein RR, Stenlöf K, Hedner J, Sjöström L (1995) Impact of obstructive sleep apnea and sleepiness on metabolic and cardiovascular risk factors in the Swedish Obese Subjects (SOS) Study. Int J Obesity 19:410-418

9. Hu FB, Willet WC, Colditz GA, et al. (1999) Prospective study of snoring and risk of hypertension in women. Am J Epidemiol 150:806-816

10. Hu YR, Goldman N (1990) Mortality differentials by marital status: an international comparison. Demography 27:233-250

11. Issa FG, Sullivan CE (1996) Alcohol, snoring and sleep apnea. J Neurol Neurosurg Psychiatry (1982) 45:353-359

12. Jagger C, Sutton CJ (1991) Death after marital bereavement-is the risk increased? Stat Med 10:395-404

13. Jones DR (1987) Heart disease mortality following widowhood: some results from the OPCS Longitudinal Study, Office of Population Censuses and Surveys. J Psychosom Res 31:325-333

14. Kasl SV (1984)

15. Kump K, Whalen C, Tishler PV, et al. (1994) Assessment of the validity and utility of a sleepsymptom questionnaire. Am J Respir Crit Care Med 150:735-741

16. Lavie P (1981) Sleep habits and sleep disturbances in industrial workers in Israel: main findings and some characteristics of workers complaining of excessive daytime sleepiness. Sleep 4:147158 
17. Lindberg E, Janson C, Svardsund K, et al. (1998) Increased mortality among sleepy snorers: a prospective population-based study. Thorax 53:631-637

18. Lindquist CH, Reynolds KD, Goran ML (1999) Sociocultural determinants of physical activity. Prev Med 29:305-312

19. Malcolm JA, Dobson AJ (1989) Marriage is associated with a lower risk of ischaemic heart disease in men. Med J Austr 151:723-724

20. Mallon L, Broman J-E, Hetta (2002) Sleep complaints predict coronary artery disease mortality in males: a 12-year follow-up study of a middle- aged Swedish population. J Int Med 251:207-216

21. Mellström D, Nilsson A, Oden A, et al. (1982) Mortality among the widowed Swedes. Scand J Soc Med 10:33-41

22. Mendes de Leon CF, Appels AW, Otten FW, Schouten EG (1992) Risk of mortality and coronary heart disease by marital status in middle-aged men in The Netherlands. Int J Epidemiol 21:460-466

23. Montaut-Verient B, Teculescu D, Mayeux L, et al. (2000) Anomalies "mineures" de la filière rhino-oro-pharyngée et troubles ventilatoires du sommeil: une étude épidémiologique en Lorraine. J Français ORL 49:140-144

24. Partinen M, McNicholas WT (1998) Epidemiology, morbidity and mortality of the sleep apnoea syndrome In: McNicholas WT (ed) Respiratory disorders during sleep. European Respiratory Society Monograph. no. 10 Sheffield, 63-74

25. Rahman O (1993) Excess mortality for the unmarried in rural Bangladesh. Int J Epidemiol 22:445456

26. Rosengren A, Wedel H, Wilhelmsen L (1989) Marital status and mortality in middle-aged Swedish men. Am J Epidemiol 129:54-64

27. Strohl KP, Redline S (1996) Recognition of obstructive sleep apnea. Am J Respir Crit Care Med 154:279-289

28. Teculescu D, Guillemin F, Hannhart B, et al. (2003) Reliability of the Wisconsin Sleep Questionnaire: a French contribution to international validation. J Clini Epidemiol 56:436-440

29. Teculescu D, Hannhart B, et al. (2002) Who are the "occasional" snorers?. Chest 122:562-568

30. Trabert G (1997) Health status and medical care accessibility of single, homeless persons. Gesundheitswesen 59:378-386

31. Venters M, Jacobs Dr Jr, Pirie P, et al. (1986) Marital status and cardiovascular risk: the Minnesota Heart Survey and the Minnesota Heart program. Prev Med 15:591-605

32. Young T, Finn L (2001) Modifiable risk factors for early stage SDB ("simple snoring”) (abstract). Am J Respir Crit Care Med 63:A932.

33. Young T, Palta M, Dempsey J, et al. (1993) The occurrence of sleep-disordered breathing among middle-aged adults. N Engl J Med 328:1230-1235

34. Young T, Peppard PE, Gottlieb DJ (2002) Epidemiology of obstructive sleep apnea. A population health perspective. Am J Respir Crit Care Med 165:1217-1239 